\title{
A COVALENTLY LINKED DNA-RNA MOLECULE FROM HUMAN LEUKEMIA CELLS *
}

\author{
S. T. Barker, H. Kurtz, B. A. Taylor, \\ and $\mathrm{W}$. Wilbur Ackermann \\ Department of Epidemiology and Virus Laboratory \\ University of Michigan, Ann Arbor, Michigan
}

\section{Received January 2, 1973}

SUMMARY. An enzyme complex was prepared from the cytoplasm of a continuous line of monocytic human leukemia cells is otopically labeled in culture. Such preparations carry out RNA dependent DNA synthesis using endogenous primers and templates and contain radioactive RNA and DNA. The endogenous $\left[{ }^{3} \mathrm{H}\right]$-thymidine labeled DNA in these preparations was characterized by sedimentation in $\mathrm{Cs}_{2} \mathrm{SO}_{4}$ and neutral sucrose density gradients in conjunction with heat and alkali treatments and digestion with $\mathrm{RNase}$. The resulting data support a view that a portion of the DNA is covalently linked to a larger piece of RNA in a molecule with a sedimentation coefficient of approximately 24S. This in turn may be hydrogen bonded to additional DNA in the native state.

An enzyme complex (CEC) was prepared from the cytoplasm of a continuous line of human granulocytic leukemia cells (Z 529) which in vitro synthesized DNA, by an RNA dependent reaction, using its own endogenous nucleic acid primers and templates (1). Subsequently, the same method yielded a similar complex from a continuous line of monocytic human leukemia cells (J-111). CEC prepared from J-111 cells, whose DNA and RNA were isotopically prelabeled during culture, and purified by rate zonal centrifugation in sucrose density gradients could be shown to contain DNA and RNA (unpublished results of the authors). Evidence presented in this paper supports the view that a part of the DNA of this complex is covalently linked to a relatively larger RNA molecule.

\section{MATERIALS AND METHODS}

[Methyl $-{ }^{3} \mathrm{H}$ ] thymidine $(\mathrm{d} T)(23 \mathrm{Ci} / \mathrm{m} \mathrm{mol})$ and NCS tissue solubilizer were obtained from Amersham/Searle Corp. Sucrose (ultra pure, special density

Abbreviations: $\mathrm{SSC}(0.15 \mathrm{M}$ sodium chloride $-0.015 \mathrm{M}$ sodium citrate); PPLO (pleuropneumoniamlike organisms); PPO (2,5 diphenyloxazole); POPOP (1, 4-bis-[2-(5-phenyloxazolyl] -benzene); CEC (cytoplasmic enzyme complex); EGT A (ethyleneglycol-bis ( $\beta$-aminoethyl ether)-N, $N^{1}$-tetraacetic acid); SDS (sodium dodecyl sulfate).

*Supported in part by National Cancer Institute, Contract NIH-NC1-C-72-7314 
gradient grade) was purchased from Schwarz/Mann. Cesium sulfate was purchased from Hruden Laboratory Products (Ann Arbor, Mich.). RNase A and RNase $T$ were purchased from Worthington Biochem. Corp. and were used after heating at $100^{\circ} \mathrm{C} / 10 \mathrm{~min}$. EGTA was obtained from Calbiochem. Poly ethylene 'mini-vials', PPO and POPOP were purchased from Rochester Scientific Co., Inc.

A continuous line of monocytic leukemia cells $(\mathrm{J}-111)(2)$ was purchased from the American Type Culture Collection Cell Repository (CCL 24) and was used in these experiments. This cell line has been maintained by passage at four or five day intervals. PPLO tests have been negative. Bellco disposable rollex bottles were seeded with $20 \times 10^{5}$ cells in $100 \mathrm{ml}$ of Eagle's medium (3) supplemented with $15 \%$ fetal bovine serum, 100 units $/ \mathrm{ml}$ of penicillin, 0.1 $\mathrm{mg} / \mathrm{ml}$ of streptomycin, and $0.5 \mu \mathrm{g} / \mathrm{ml}$ of fungizone and incubated at $37^{\circ} \mathrm{C}$. On the third day, the medium was changed to Eagle's containing $2 \%$ fetal bovine serum and $0.2 \mu \mathrm{Ci} / \mathrm{ml}$ of $[3 \mathrm{H}]-\mathrm{dT}$ was added. On the fifth day, cells were harvested and the CEC was prepared as described previously (1), except the final pellet was resuspended in $0.10 \mathrm{M} \mathrm{Tris}-\mathrm{HCl}(\mathrm{pH} 8.3)-0.01 \mathrm{M}$ EGTA.

$\underline{F o r ~ C s}_{2} \mathrm{SO}_{4}$ equilibrium centrifugation, nucleic acid samples, $2.98 \mathrm{~g}$ of $\mathrm{Cs}_{2} \mathrm{SO}_{4}, 1.1 \mathrm{ml} 10 \mathrm{XSSC}$ and Sarkosyl were mixed, and then the volume was adjusted to $4.4 \mathrm{ml}$ with water. The mixture was placed in a polyallomer tube, overlaid with mineral oil, and centrifuged in a Beckman SW 39 rotor for 68 hr at $33,000 \mathrm{rpm}$ and $25^{\circ} \mathrm{C} ; 0.15 \mathrm{ml}$ fractions were collected from the bottom of the tube.

For neutral sucrose gradient sedimentation, mammalian cell RNA (labeled with ${ }^{14} \mathrm{C}$ ) was used as a molecular weight reference marker. The gradients were prepared from sucrose which had been dissolved in $0.01 \mathrm{M}$ Tris-HCl (pH 7.4) - 0.01M NaCl-0.003M EDTA--0.5\% SDS and which had been autoclaved before use. The nucleic acid sample to be analyzed was made $1 \%$ with respect to SDS and a $0.5 \mathrm{ml}$ aliquot was layered on top of a $16 \mathrm{ml}$ $5-20 \%$ sucrose gradient. Centrifugation was at $18^{\circ} \mathrm{C}$ for $16 \mathrm{hr}$ at $20,000 \mathrm{rpm}$ in a Beckman SW 27 rotor. From a hole in the bottom of the tube, $0.4 \mathrm{ml}$ fractions were collected.

Radioactivity in DNA and RNA was determined with or without prior digestion in the presence of $0.3 \mathrm{~N} \mathrm{KOH}$ at $100^{\circ} \mathrm{C} / 10 \mathrm{~min}$. or at $37^{\circ} \mathrm{C} / 18 \mathrm{hr}$. To 
samples to be tested for acid-insoluble radioactivity, $25 \mu \mathrm{l}$ of a $16 \%$ solution of calf serum was added as carrier and the concentration of cold trichloroacetic acid (TCA) was adjusted to $10 \%$. The resulting precipitate was pelleted, washed four times with cold 5\% TCA, dissolved in $0.25 \mathrm{ml}$ NCS tissue solubilizer $(7$ parts NCS to 3 parts toluene), resuspended in $5.0 \mathrm{ml}$ scintillation fluid ( 3.81 toluene, $15.2 \mathrm{~g}$ PPO, $0.38 \mathrm{~g}$ POPOP), and counted in polyethylene 'mini-vials' for $5 \mathrm{~min}$. in a Beckman LS250 liquid scintillation counter.

\section{EXPERIMENTAL AND RESULTS}

Equilibrium density centrifugation of a cytoplasmic enzyme complex prepared from [ $\left.{ }^{3} \mathrm{H}\right]$-thymidine labeled $\mathrm{J}-111$ cells and deproteinized, yielded acid insoluble ${ }^{3} \mathrm{H}$ exclusively in an unsymmetrical distribution about the $1.490 \mathrm{~g} / \mathrm{ml}$ density point with a shoulder toward higher density (Fig. 1, a). When the preparation was deproteinized and also heated $\left(100^{\circ} \mathrm{C} / 5 \mathrm{~min}\right.$. ), acid insoluble ${ }^{3} \mathrm{H}$ was found in the near-RNA density region $(1.700 \mathrm{~g} / \mathrm{ml})$, as well as in the DNA density region following equilibrium centrifugation in $\mathrm{Cs}_{2} \mathrm{SO}_{4}$ (Fig. 1, b).

Material in the RNA region of a $\mathrm{Cs}_{2} \mathrm{SO}_{4}$ gradient, described above, was recovered, heated with alkali, brought to equilibrium again in a $\mathrm{Cs}_{2} \mathrm{SO}_{4}$ gradient, whereupon acid insoluble ${ }^{3} \mathrm{H}$ was found exclusively in the DNA region $(1.490 \mathrm{~g} / \mathrm{ml}$ ) (Fig. 1, d). Similar results were obtained when the material was digested with RNase (Fig. 1, c).

The interpretation of these observations is that ${ }^{3} \mathrm{H}$ from [ $\left.{ }^{3} \mathrm{H}\right]$-thymidine is exclusively in polydeoxyribonucleotide sequences because of the metabolic specificity of thymidine (4), and because the acid insolubility of the ${ }^{3} \mathrm{H}$ is stable to alkali or RNase digestion and further, after alkali digestion the ${ }^{3} \mathrm{H}$ has a buoyant density in $\mathrm{Cs}_{2} \mathrm{SO}_{4}$ like DNA. After heating, a part of the DNA is found in the RNA region because these polydeoxyribonucleotide sequences are bound covalently by an alkali sensitive, heat stable link to RNA; ${ }^{3} \mathrm{H}$ is found only in the DNA region before heating because the covalently linked moieties may be originally hydrogen bonded to a substance with a density of DNA.

The heterogeneity and size of the acid insoluble $\left[{ }^{3} \mathrm{H}\right]$-thymidine labeled material isolated from the RNA region of a $\mathrm{Cs}_{2} \mathrm{SO}_{4}$ density gradient (described above and in Fig. 1, b) were examined by rate zonal centrifugation in a sucrose density gradient. Previous experiments indicated the alkali resistant ${ }^{3} \mathrm{H}$ 


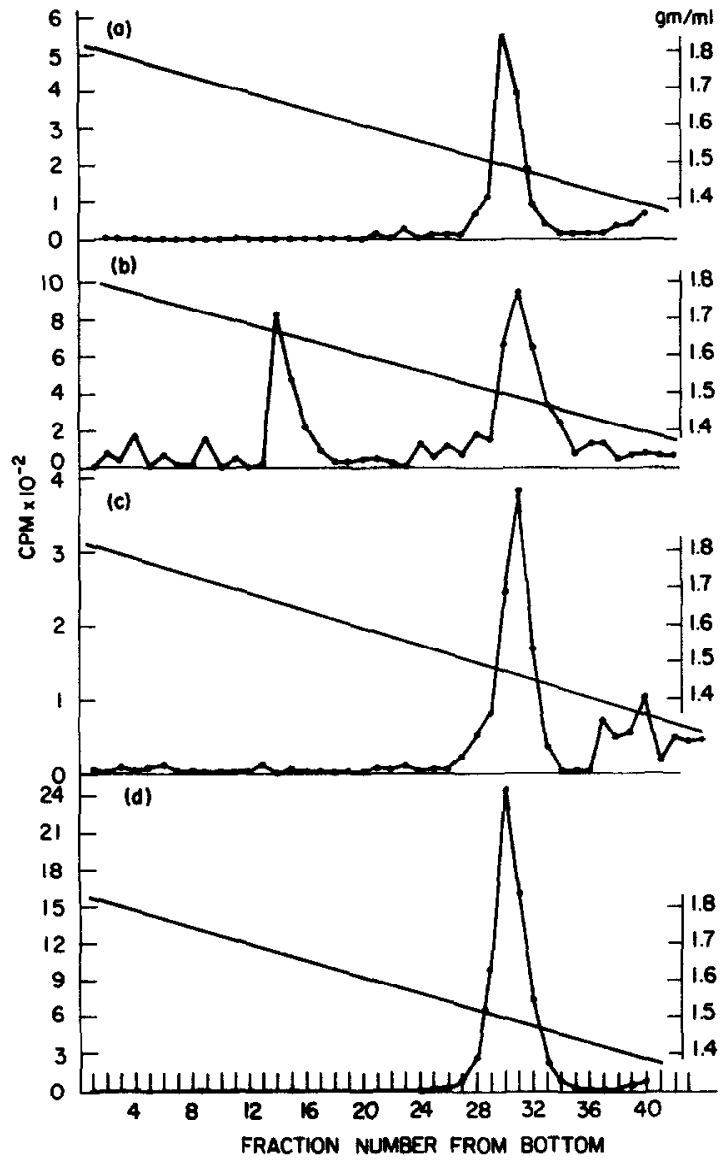

Fig. 1 Effect of heat, RNase, and alkali on the density of $\left[{ }^{3} \mathrm{H}\right]$-dT labeled nucleic acid as analyzed by $\mathrm{Cs}_{2} \mathrm{SO}_{4}$ equilibrium centrifugation.

CEC prepared from [ $\left.{ }^{3} \mathrm{H}\right]-\mathrm{dT}$ labeled $\mathrm{J}-111$ cells was treated as follows:

(a) $0.2 \mathrm{ml} \mathrm{CEC} \mathrm{was} \mathrm{mixed} \mathrm{at} 25^{\circ} \mathrm{C}$ with $0.8 \mathrm{ml}$ water, $1.1 \mathrm{ml} 10 \mathrm{X} \mathrm{SSC}$, and $0.2 \mathrm{ml} \mathrm{10 \%} \mathrm{Sarkosyl.} \mathrm{(b)} \mathrm{A} \mathrm{mixture} \mathrm{composed} \mathrm{of} 0.2 \mathrm{ml} \mathrm{CEC,} 0.5 \mathrm{ml}$ water and $0.2 \mathrm{ml} 10 \%$ Sarkosyl was heated at $100^{\circ} \mathrm{C} / 5 \mathrm{~min}$. and rapidly chilled.

(c) Two fractions from the peak of $\left[{ }^{3} \mathrm{H}\right]-\mathrm{dT}$ counts $(1.675-1.685 \mathrm{gm} / \mathrm{ml}$ in the near-RNA region of a $\mathrm{Cs}_{2} \mathrm{SO}_{4}$ gradient similar to (b) were pooled, incubated in the presence of $100 \mu \mathrm{g} / \mathrm{ml}$ RNase $A$ for $1 \mathrm{hr}$ at $37^{\circ} \mathrm{C}$, heated at $100^{\circ} \mathrm{C} / 5 \mathrm{~min}$. in $5 \%$ Sarkosyl and rapidly chilled. (d) Material from the peak of $\left[{ }^{3} \mathrm{H}\right]-\mathrm{dT}$ counts in the near-RNA region $(1.675-1.690 \mathrm{gm} / \mathrm{ml})$ of a $\mathrm{Cs}_{2} \mathrm{SO}_{4}$ gradient similar to (b) was pooled, heated at $100^{\circ} \mathrm{C} / 10 \mathrm{~min}$, in $0.1 \mathrm{~N} \mathrm{NaOH}$, rapidly chilled and neutralized with HCl. Following these various treatments, each sample was centrifuged to equilibrium in a $\mathrm{Cs}_{2} \mathrm{SO}_{4}$ gradient as described in Methods.

labeled material was linked to RNA, therefore, the isolated material was centrifuged in the sucrose gradient with and without prior alkali digestion. Thus information about the RNA-DNA linked molecule, as well as about the DNA 


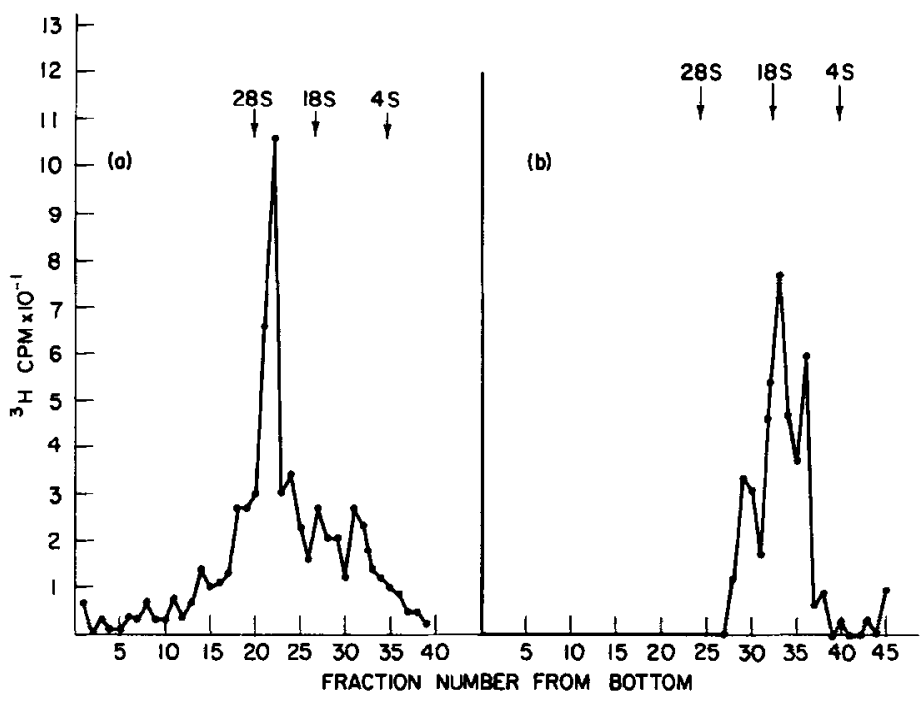

Fig. 2 Neutral sucrose gradient sedimentation of RNA and DNA from the

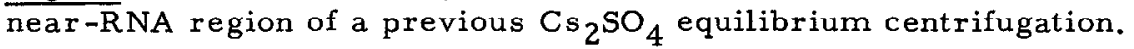

Fractions were taken from the RNA region of a $\mathrm{Cs}_{2} \mathrm{SO}_{4}$ gradient similar to (b) in Fig. 1, dialyzed against $0.01 \mathrm{M}$ Tris $-\mathrm{HCl}\left(\mathrm{pH}^{2} .4\right)-0.01 \mathrm{M} \mathrm{NaCl}-0.003 \mathrm{M}$ EGTA at $4^{\circ} \mathrm{C}$, and divided into two equal aliquots. Aliquot (a) was left untreated. Aliquot (b) was heated at $100^{\circ} \mathrm{C} / 10 \mathrm{~min}$. in the presence of $0.1 \mathrm{~N}$ $\mathrm{NaOH}$, rapidly chilled, neutralized with $\mathrm{HCl}$ and ${ }^{14} \mathrm{C}$ RNA marker was added. $0.5 \mathrm{ml}$ of both (a) and (b) were layered on $5-35 \%$ sucrose gradients and centrifuged (Methods). Fractions were collected from both gradients and fractions from (a) were heated in $0.3 \mathrm{~N} \mathrm{KOH}$ for $10 \mathrm{~min}$. at $100^{\circ} \mathrm{C}$. Acid-insoluble radioactivity was then determined on both gradients.

component alone was obtained. The sedimentation coefficients of the ${ }^{3} \mathrm{H}$ containing materials were characterized by their positions in the gradients and by reference to ${ }^{14} \mathrm{C}-\mathrm{RNA}$ standard markers (5).

Single stranded ribosomal ${ }^{14} \mathrm{C}-\mathrm{R} N A$ standards may not be appropriate for accurately estimating the $S$ values of single stranded DNA or the RNA-DNA linked polymer. Despite this, several conclusions can be drawn from these results (Fig. 2).

First, the RNA-DNA molecules are heterogenous as obtained; there is a principal component which behaves as would 24. 1S RNA, but one of the minor components has a value of 30.35 . These values should be regarded as minimal estimates of size since the molecules risk degradation in handling. After alkali digestion, the acid insoluble ${ }^{3} \mathrm{H}$ is not only converted to material of lower density (as indicated by the $\mathrm{Cs}_{2} \mathrm{SO}_{4}$ gradient, Fig. 1, d) but the major 
part is reduced to smaller pieces. The sedimentation coefficients of the principal peaks are estimated to be $22,16.6$ and 12. 3S.

Second, if the formulation of Spirin (6) developed for single stranded RNA (molecular weight $=1550 \times \mathrm{s}^{2} .1$ ) is valid for approximating the molecular weights of these single stranded molecules, its application would give molecular weights in the range of one to two million for the RNA-DNA polymers, while the principal DNA components obtained after alkali digestion would be 3,6 and $10 \times 10^{5}$ daltons respectively.

The buoyant density of the RNA-DNA molecule in $\mathrm{Cs}_{2} \mathrm{SO}_{4}$ suggests the RNA is in great excess of the DNA (7). If the molecule is linear and single stranded, the maximum number of RNA sequences would be no more than twice that of the DNA (if RNA were linked to each end of the DNA). The RNA sections of the molecule would then be at least as large as the DNA which in some cases had sedimentation coefficients of 16.6 to $22 \mathrm{~S}$.

\section{DISC USSION}

Molecules of RNA covalently linked to DNA have been produced in vitro by enzyme action of avian myeloblastosis virions. It was suggested that the RNA sequence was small, relative to the DNA, and functioned as a primer for DNA synthesis (8). Further evidence for such a reaction leading to covalently linked RNA-DNA was reported in E. coli (9) and also in T4 phage (10)

Evidence for a covalently linked RNA-DNA polymer presented here is essentially of the type found in the reports cited above. However, there are some dissimilar aspects besides the molecule being produced in situ and isolated from the cytoplasm of human leukemia cells. Demonstration of the molecule is not dependent upon a short pulse label; the RNA sequences are inferred to be larger than the DNA and large relative to the RNA implicated previously in such polymers. While the size suggests the RNA component is an unlikely primer, it does not preclude a combined primer-template which functions in the production of the RNA-DNA covalent polymer which may then be an intermediate in an RNA dependent DNA synthesis.

\section{REFERENCES}

1. Ackermann, W.W., Murphy, W., Miller, B.A., Kurtz, H., and Barker, S. T., Biochem. Biophys. Res. Comm. 40, 723 (1971). 
2. Osgood, E. E., Blood 10, 1010 (1955).

3. Eagle, H. , J. Exptl. $\overline{M e d}$, 102, 37 (1955).

4. Shatkin, A.J. In: Fundamental Techniques in Virology. Edited by K.

Habel and N. P. Salzman. pp. 238-241 (1969).

5. Martin, R. G., and Ames, B. N. J. Biol. Chem. 236, 1372 (1961).

6. Spirin, A.S. Prog. Nucleic Acid Res. 1, 301 (1963).

7. Chamberlin, M., and Berg, P.J. J. Mol. Biol. 8, 297 (1964).

8. Verma, I. M., Meuth, N. L., Bromfeld, E., Manly, K., and Baltimore, D. Nature New Biol. 233, 131 (1971).

9. Sugino, A., Hirose, S., and Okazaki, R. Proc. Nat. Acad. Sci. USA 69,1863 (1972).

10. Speyer, J. F., Chao, J., and Chao, L. J. of Virol. 10, 902 (1972). 